\title{
Living Machines: Metaphors We Live By
}

\author{
Nora S. Vaage $\mathbb{D}$
}

Received: 4 October 2018 / Accepted: 27 October 2019 /Published online: 10 December 2019

(C) The Author(s) 2019

\begin{abstract}
Within biology and in society, living creatures have long been described using metaphors of machinery and computation: 'bioengineering', 'genes as code' or 'biological chassis'. This paper builds on Lakoff and Johnson's (1980) argument that such language mechanisms shape how we understand the world. I argue that the living machines metaphor builds upon a certain perception of life entailing an idea of radical human control of the living world, looking back at the historical preconditions for this metaphor. I discuss how design is perceived to enable us to shape natural beings to our will, and consider ethical, epistemological and ontological implications of the prevalence of this metaphor, focusing on its use within synthetic biology. I argue that we urgently need counter-images to the dominant metaphor of living machines and its implied control and propose that artworks can provide such counterimages through upsetting the perception of life as controllable. This is argued through discussion of artworks by Oron Catts and Ionat Zurr, by Tarsh Bates and by $\mathrm{Ai}$ Hasegawa, which in different ways challenge mechanistic assumptions through open-ended engagement with the strangeness and messiness of life.
\end{abstract}

\footnotetext{
N. S. Vaage $(\bowtie)$

Department of Philosophy, Maastricht University, Grote Gracht 90-92, 6211 SZ Maastricht, The Netherlands e-mail: n.vaage@maastrichtuniversity.nl

N. S. Vaage

History, Culture and Media, Faculty of Social Sciences, Nord University, Postbox 1490, 8049 Bodø, Norway
}

Keywords Mechanism - Machine metaphor - Art . Philosophy of biology $\cdot$ Synthetic biology

\section{Introduction}

Metaphors of machinery and computation abound within biology, from 'genes as code' or 'biological chassis' to 'microbial cell factory'. These metaphors are especially prevalent in mainstream media science communication and in science education. This paper takes as a starting point Lakoff and Johnson's argument in Metaphors We Live By [1] that such language mechanisms shape how we understand the world. While the 'living machines' metaphor is increasingly prevalent in recent years with the influx of bioinformatics and emergence of new bioengineering fields such as synthetic biology, its history can be traced beyond the Mechanical Philosophy of the Scientific Revolution, to the mechanistic thoughts of the pre-Socratic Greeks.

In this paper, I will, after discussing the conceptualisation of metaphors, start by addressing aspects of mechanistic philosophy ${ }^{1}$ that form an important

\footnotetext{
${ }^{1}$ Several philosophers have pointed to the multiple meanings of the term 'mechanism' in biology and attempted to distinguish these [2-4]. I will here follow Nicholson's [3] distinction between three meanings: (a) mechanistic philosophy, which he calls mechanicism, (b) machine mechanism, the inner workings of any machine-like structure, which are today mostly referred to simply as 'machines', and (c) causal mechanism, a mode of explanation of a relevant causal process within an organism (as in 'the mechanism of heredity'). While the latter is the most common use of 'mechanism' in contemporary biology, and has been the subject of extensive philosophical enquiry in the past two decades (e.g. [4, 5]), these meanings do tend to get conflated in both scientific and philosophical discussions.
} 
historical backdrop for the current use of machine metaphors. I argue that the living machines metaphor contributes to an idea of radical human control of the living world and that the success of synthetic biology in spreading visions of how its engineering approach will change life as we know it means that the machine metaphor becomes further ingrained in societal perceptions of living organisms. I discuss how design in synthetic biology is perceived to enable us to shape natural beings to our will, and briefly consider ethical, epistemological and ontological implications of the prevalence of this. I argue that other metaphors do not currently serve to properly balance the living machines metaphor, and we urgently need to search for such balance in the face of the dominant metaphor. Therefore, I look to artworks that set out to challenge the notion of life as machinery for quite other, equally spectacular visions. $^{2}$ The evocative, embodied presence of art can, I argue, serve as a counterbalance to the predominance of a metaphor that frames life in a rather reductive and inaccurate manner. I discuss three artworks that are themselves concerned in various ways with control, but that problematize the extent to which we can control and understand living organisms. Drawing on artworks in the discussion of synthetic biology is particularly appropriate, since a subsection of this field, whose efforts to engineer biology is focused on creativity, play, and the spectacular, explicitly values aesthetics and the creative input of artists and designers $[6,7]$.

\section{Metaphors We Live By}

Lakoff and Johnson, in Metaphors We Live By, argue that metaphor 'is not just a matter of language, that is, of mere words [...] human thought processes are largely metaphorical' ([1]: p. 6). They hold that we form systematic ways of talking about a certain overarching concept, informed by the metaphorical concept itself. For instance, they use the metaphor 'argument is war' and show how it is used to describe how we argue: we 'win', and 'lose' arguments, 'shoot down' the 'opponent', 'attack' or 'defend a position' and so on ([1]: pp. 5-6). These ways of speaking become so much a part of

\footnotetext{
$\overline{2}$ Definitions of 'life' have been contested at least since the time of Aristotle, and there is still not one, clear distinction between life and non-life. Discussing these definitions is beyond the scope of the present paper, but it is important to note that referring to 'life' generically is itself a somewhat reductive approach and is done heuristically.
}

our everyday speech and thought patterns that we hardly think of them as metaphors at all. But Lakoff and Johnson ask us to imagine a culture where argument, instead, was perceived as a dance. This is a potent description of the power of metaphors, in language, images and so on, to shape how we think about the world. In making us focus on certain aspects of a concept, other aspects may be kept out of focus.

This cognitive linguistic view challenged what was up until the 1980s the predominant idea of metaphors, as a component of language distinct from the literal, with mainly aesthetic or diversionary purposes [8,9]. Lakoff and Johnson's lucid argument has led to new realisations about how metaphorical language shapes the way we think. A number of scholars have showed how this applies to science, also from insider's perspectives [10-12]. As Laura Otis argues about the connections nineteenth century scientists made between nerves and networks of telegraph lines, such analogies have real conceptual force: 'metaphors do not 'express' scientists' ideas; they are the ideas' ([13]: p. 48). In the context of synthetic biology, McLeod and Nerlich ([14]: p. 2) posit that 'the language we use to make a better world matters; words matter; metaphors matter'.

The metaphor of life as machinery is widespread, and for good reasons. It is hard to imagine how a cell operates, since it functions at such a different scale from our own. Imbuing it with a metaphor enhances particular understandings, which can be quite helpful. Nicholson [9] has distinguished between three major roles for scientific metaphors: (1) theoretical, which is important to scientific understanding, (2) heuristic, which can be key to scientific discovery and (3) rhetorical, which is central to scientific communication. He emphasises that for the most pervasive metaphors, all three roles can be in play. This is certainly the case for the machine conception of life. As a 'grand metaphor' [8], it inspires a whole range of sub-metaphors, some of which will be discussed later in the paper.

\section{Universal Mechanism}

The idea that the universe is comparable to a large mechanism, which runs rationally and predictably like a machine, has existed since the ancients. The Babylonians were able to predict celestial occurrences, and the Greeks inherited from them the idea that heavenly motions were regular and could be rationally 
understood through mathematics and geometrical models. Many philosophies of the time drew on these perspectives in seeking to understand the natural world, most prominently atomist theories deriving from Democritus's materialist philosophy and developed by Epicurus, and most of Stoic physics.

While traditionally, it has been assumed that materialist, mechanistic theories in astronomy and biology took their cue from developments of technology and increased understandings of machinery, de Solla Price [15] argued that it was the other way around: mechanistic philosophy led to the making of increasingly advanced automata, which brought about much of the technology we now take for granted. He supported this by discussion of the development of mechanisms to study the cosmos from the time of the Greeks. Rational, mechanistic explanations of the universe as a mechanism led to a focus on societal development quite different from that required by vitalism and theology.

There is little doubt, however, that by the time of the Scientific Revolution, technology and mechanistic thought developed in tandem. Building on religious traditions from the Scholastics, humans were seen as unique in the cosmos in exhibiting proof of souls. Thomas Aquinas' Summa Theologica (written 1265-1274) held forth that animals show orderly behaviour and this has often been taken as cause for viewing them as biological machines. This view was famously expressed by Descartes $[16],{ }^{3}$ who drew a clear line between human minds and the rest of the biological world, on which he did have a mechanist view. His prioritising of what can be known through the rational mind over what could be experienced broke with the established Aristotelian adage that 'there is nothing in the mind that was not first in the senses'. Although it was disputed by some of his contemporaries, including Spinoza, the dualist separation between the thinking substance and the substance of extension in space would be core to major strands of philosophy and science after Descartes [17].

Mechanistic thought at his time came into prominence, although it was far from unitary, as can be seen in the atomist theory of Francis Bacon and the materialist, possibly atheist approach of Thomas Hobbes. Their view appears to have gone well beyond metaphor to an ontic perception of the bete machine, as a creature that was, in every way that mattered for analysis, a machine. There is

\footnotetext{
$\overline{3}$ Descartes' mechanistic and dualistic ideas were further developed in the 1648 book L'Homme.
}

little doubt that this way of thinking furthered scientific discovery. Using analogies of familiar items is a way of bringing closer realms that we cannot access directly, such as the inside of the human body and, later, the radically different scales of the nano realm [2].

A central tenet of the mechanistic worldview of the Scientific Revolution was the notion of an intelligent designer [3, 4]. For Descartes, as for the next generations of seventeenth- and eighteenth-century scholars, the laws of nature were established by God. The clockwork universe theory, inspired by the Newtonian laws of motion, was popular amongst deists who saw the world as a mechanical clock wound up by the Creator. However, the close linkage between mechanistic philosophy and the idea of intelligent design was criticised by Hume [18]. He let Philo, the voice of his ideas, point out that our experience with design is limited to human practices, and that we should not presume on such spurious grounds that we have a model for the workings of the entire universe. To prove his point, Philo speculated that both an animal and a plant, in their ability to selfmaintain and regenerate, might be closer analogies for the universe than the existing machine analogy [18].

With Charles Darwin's theory of evolution by natural selection, presented in The Origin of Species in 1859, a naturalistic alternative to the intelligent design account became plausible. After this period, the idea of nature as a machine no longer necessarily includes the meaning 'designed by an intelligence' ([4]: p. 289). Strikingly, this did not result in mechanistic language being stripped of its ontic significance. Rather, it seems evolutionary biology adapted to mechanistic thought, so the idea of 'designed machines' became the notion of 'evolved machines' [3, 19]. However, the conception of design still exists within creationism and other religious movements [19], and within ethics is important in the natural law argument that human beings 'play God' when they manipulate nature [20].

Throughout the centuries described above, mechanistic thought waged for dominance with vitalism in perceptions of living things. Vitalist conceptions of life were antireductionist, but also dualistically distinguished life from mere matter, following Aristotle's division between form and matter [21, 22]. In vitalist thought from the eighteenth century onwards, this dualism became less marked, but the idea remained that living things contain a vital force. Vitalism played an important role in critiquing mechanism for its tendency towards reductionism and generalisation to (too) few scientific laws. Mechanism, concurrently, 
challenged the tendency in vitalism towards absolute distinction between the living and the non-living, increasingly supported by findings that living things were made from the same substances as non-living objects, and that the principle of conservation of energy was equally applicable to both [21]. After those challenges, vitalism regrouped to stress organisational and structural differences between life and the non-living, focused on the complexity and irreducibility of living beings. This position became known as holism, and continued to be a counterpoint to mechanism in polemical discussions [2, 21].

In the early twentieth century, mechanistic thinking in biology surged, spurred, amongst other things, by a desire to make biology into a 'hard science' following the model of physics and chemistry. Jacques Loeb's influential The Mechanistic Conception of Life, published in 1912, argued vigorously that everything in life resulted from physicochemical processes. This was the same year as Stéphane Leduc published his book $L a$ Biologie Synthétique (possibly the first use of the term synthetic biology), which presented similar arguments to Loeb's about a continuum between life and non-life, but without the engineering drive for control [23, 24]. At the same time, vitalist ideas resurged, importantly through works of Bergson and biologist philosophers Uexküll and Driesch $[2,22]$. However, holistic approaches, even those that shared mechanism's materialist epistemology, were increasingly ignored and disdained by practicing scientists, on partly political grounds due to their similarities to Nazi 'organicism' and Marxist dialectical materialism [2, 25]. Jacob and Monod's work on genetic circuits in the 1960s refined the engineering approach developed by Loeb and his contemporaries, and introduced the analogy between genes and computer programs with their 'genetic program'. In describing themselves as being the first to truly aim for engineering biology, today's synthetic biology practitioners are curiously similar to their twentieth century predecessors [26].

The machine metaphor in biology, then, has a long prehistory. It also coexists with other metaphors, which both contend and conspire to make up the overall ideas within biology. The two other grand metaphors within biology are the language/book metaphor and the organic system metaphor [8, 14]. ${ }^{4}$ Gilbert \& Sarkar [25] viewed

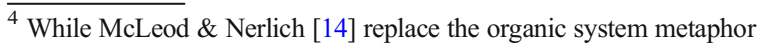
with the computer metaphor, I argue that this can be viewed as part of the machine master metaphor and that it is important to keep in mind that the idea of the 'organism' is also a heuristic.
}

language as 'an excellent analogy' for organicist, materialist holism: 'The meaning of the sentence is obviously determined by the meaning of the words; but the meaning of each word is determined by context of the sentence it is in' ([25]: p. 2). This illustrates organicists' emphasis on the emergent properties arising through the interaction of biological parts.

Although Konopka mentioned a high likelihood of overlap between the three grand metaphors, neither he nor Gilbert and Sarkar emphasised the degree to which information technologies have in recent years subsumed the language metaphor to the machine conception. Terms such as 'information', 'editing' and 'code' now bring up the image of computer software. For bioengineering, the information metaphor entails a distinction between 'software' and 'hardware', bringing back a version of Cartesian dualism in distinguishing between the information contained in the genome and the cell itself [9]. Information technology has radically transformed biology and brought about new fields such as synthetic and systems biology. Computers potentially enable greater understanding of complexity, through their ability to process huge amounts of information, which has led to the development of various 'omics' technologies. This can also be considered a holistic view of the organism, without the 'fuzzy' connotations of vitalism [25]. Microbiome research and epigenetics have both increasingly sought to understand the complex interactions that define any organic system [14]. These approaches now co-exist with bioengineering approaches such as synthetic biology, where the view of living machines is fore-fronted. This situation serves to make us think, again, about the meaning of life and our situations as humans within a complex environment.

\section{Biological Machines in Synthetic Biology}

Synthetic biology, as a field, is defined as 'the engineering of biology: the synthesis of complex, biologically based (or inspired) systems, which display functions that do not exist in nature' [27]. Synthetic biology (hereafter synbio) involves bioengineering at different scales, with two main approaches: (a) bottom-up, constructing organisms 'from scratch', or (b) top-down, reducing the complexity of existing organisms to levels that are workable and understandable [28]. Beyond this broad distinction, synbio encompasses multiple research programs, from synthetic genomics and protocell 
research to 'unnatural molecular biology', which seeks to create entirely new molecular biologies, from different amino acids than those existing in nature to chiral molecular structures (mirror-image life forms, imagined to be applicable even to human beings) $[6,19]$. In recent years, advances within genetic sequencing and genome editing $[29,30]$ make engineering of mammalian organisms more feasible. While traditional genetic engineering is often described as 'cut-and-pasting' genes [14], synbio aims to go beyond this. Since the mid-2000s, synthetic biologists have defined their work in opposition to genetic engineering, as seeking to 'create' completely new biological systems or organisms [31, 32]. The aims of these projects vary widely, from bioremediation to synthesis of valuable substances such as drugs, chemicals or biofuels.

The epistemological assumption remains the same, however. As Keller [24] has argued, the 'synthesis' (putting something back together) of synthetic biology does not have the same relationship to 'analysis' (picking something apart in order to understand it) as previous modes of science. In synbio, synthesis does not necessarily come after analysis. Indeed, '[k]nowledge as making might be said to be the first credo of synthetic biology' ([24]: p. 293). This idea that making is knowing and building is understanding is integral to what is frequently called 'the engineering mindset' [30]. The novelty of the synbio engineering mindset is often emphasised both by practitioners and social scientists $[31,33]$, although, as the previous section has shown, there is a certain continuity to this approach.

While the actual work that goes on in synbio laboratories varies widely, an idealised engineering vision has become important to the field's identity $(34,30]$. This entails that engineering means standardisation of components, decoupling of a project into smaller parts that can then be assembled, and reduction of the messy complexity of life to a level at which it can be controlled and useful [31]. Viewing living organisms as intricate machines, synthetic biologists seek to understand and adapt them by taking them apart, isolating their functional components, and using that partial understanding to remove what is not needed, insert synthetic DNA, and thus design a new, useful entity [19].

While biology after Darwin related to the idea of evolved machines rather than designed machines, in synbio, the idea of 'design' resurfaces at full strength but now it is design at the hands of humans, rather than God. Boldt ([34]: p. 2) suggests that this might be because 'if one succeeded in explaining organisms or parts of organisms as if they were designed to fulfill a specific purpose, this is to say that one succeeded in identifying causal relations in organisms that allows for their purposeful redesign and reengineering.' Rational design of predictable, reliable systems, a biological Taylorism, is the ultimate goal. This is repeatedly emphasised in synbio through the abundance of terms such as 'genetically engineered machines' [35], 'genetic circuits' [29] and 'multipart assembly' [36]. Most of these terms are inherited from genetics and molecular biology, including the idea of the genome as a 'blueprint' of the organism, containing all the information necessary to develop the final product [14, 22].

The approach to engineering presented by synthetic biologists has, as has been pointed out repeatedly [26, 37] been rather reductive. Engineering is elsewhere described as a social, economic and practical endeavour as well as a scientific one, and even as 'the use of heuristics and available resources to accomplish desired changes in situations that are poorly understood' (Koen 2003: p. 28, discussed in [37]: p. 652). However, influential synthetic biologists have defined it more narrowly. Calvert ([26]: p. 410) quotes Tom Knight describing the engineer's attitude to complexity: 'a biologist is delighted with complexity. The engineer's response is: "How can I get rid of this?"' Even though other fractions of the field relate less to this ideal, it has become core to the identity of synbio [38]. The ideal remains strong even as there is increasing acknowledgement that the idealised computer-based design plan followed by execution in the organism is far from the reality. What is actually done at present is more often closer to 'tinkering' [26], involving iterative processes of explorative experimentation and extensive troubleshooting [39].

The international Genetically Engineered Machine competition (iGEM) in synbio, started in 2004, involves students in using and developing standardised biological parts, called BioBricks ${ }^{\mathrm{TM}}$ (see e.g. [40]), to design microorganisms with novel properties. These parts are then added to the Registry of Standardised Biological Parts and 'can be mixed and matched to build synthetic biology devices and systems' [35]. The competition has been very successful as an educational venture, growing year by year, and including 344 multidisciplinary teams from all over the world in 2018 [35]. The competition is recognised as an important factor in the development of the engineering identity of the field, and has given cause to a large amount of publicity [33]. Another effect of this 
competition has been to imbue synbio with a sense of 'fun' and 'coolness' [26], and the idea that it is indeed easy to create new life using modular systems. Yet, very few standardised parts are actually reused. This seems to reflect a low trust in the standards, which is no wonder, given that the requirements for accepting a new BioBrick into the registry are not very rigid [41]. The ideal of modularity, we see, is more ideal than reality at this point, and the comparison of the genetic parts to simple, rectangular Lego blocks that can be added onto each other in predictable ways is misleading.

Modular systems are an important aim for several reasons, but interesting to mention is the open source ideology that is often cited [26]. Synbio is through its focus on standardisation, 'deskilling' and open source one of the more accessible fields of science and has been important in opening up biology to do-it-yourself (DIY) practices. DIY biology (DIYbio) is a non-institutional phenomenon of citizens working with biology, sometimes with a 'hacker' mentality [26, 42]. Indeed, also within the institutional synbio communities it is not uncommon to refer to one's work as 'hacking life', which may, like tinkering, be a more appropriate analogy than rational design [26].

It is important to state that most scientists today do not, contrary to some of their mechanist predecessors, assume that the living organisms they work with are exactly like machines (see e.g. [43, 44]). Implicitly or explicitly, this metaphor is used heuristically. However, especially in communicating knowledge to general audiences and students, the heuristic nature of the metaphor tends to get lost $[9,22,45]$. This is particularly so in the more spectacular synbio approaches, which make far-reaching claims about the creation of novel living organisms.

Media coverage of synbio in the Western context [33] was generally driven by breakthrough events such as the J. Craig Venter Institute's artificial version of the Mycoplasma mycoides genome, presented as the world's first selfreplicating, synthetic bacterial cell [46], and by key practitioners' visions of future applications, such as George Church's comments from 2012 onwards on the potential to reengineer Neanderthals and woolly mammoths [6]. Overall, a handful of synbio practitioners have been able to steer public perceptions more than their genetic

\footnotetext{
${ }^{5}$ Craig Venter described the cell 'Synthia' flippantly in a news story as 'the first species to have its parent be a computer' [47]. Although acknowledged as a breakthrough event, many experts agreed that it did 'not amount to creating life as either a scientific or a moral matter' [48].
}

engineering colleagues, successfully constructing more positive public perceptions of synbio [33, 49]. What gives cause for concern is that these are largely the researchers that embrace the spectacular science vision, and communicate the machine metaphor with few reservations. These grand visions communicate absolute faith in human ability to eventually control our environment completely, leading to the eradication of diseases, enhancement of positive qualities and fulfilment of all our desires. As is the case with the new genome editing techniques, synbio communications to the public have over-emphasised the amount of control and standardisation that is currently possible, in their eagerness to show the validity of the machine metaphor [14].

\section{Ontological, Epistemological and Ethical Implications of the Machine Metaphor}

Visual studies scholar W.J.T. Mitchell asked in 2002: 'What does it mean when the paradigmatic object on the assembly line is no longer a mechanism but an engineered organism?' ([50]: p. 487). Mitchell pointed out, referring to Walter Benjamin's work on technological reproduction, that in what he termed the age of biocybernetics, 'reproduction' is no longer about mass production of objects or images, but about biological reproductive processes. One of the important distinctions between these two is that we cannot expect exact copies of biological machines. Life will evolve, mutate, behave in unexpected ways, and is not as easily fixed as computer code [9, 19, 34, 41].

Nicholson [9] has argued that organisms are distinct from machines in that the latter are extrinsically purposive, and the former intrinsically so. The intrinsic purposiveness of organisms 'is grounded on the fact that they are selforganising, self-producing, self-maintaining, and selfregenerating' ([9]: p. 163), with an aim towards maintaining and propagating themselves. In machines, the above processes are externally organised, for a range of purposes determined by external agents. This boundary is partially blurred through bioengineering approaches such as synbio, as human agents seek to determine the purposes of organisms-as-machines. Another key distinction, however, is maintained: in a machine the parts are created before, and often independent of, the whole they constitute, whereas in an organism parts exist in a state of collective interdependence. If I know the function of individual machine parts, I can reliably predict the overall behaviour of the 
machine $[9,34]$. The ontological assumption that the same goes for a living organism leads to synbio's focus on biological parts, minimal genomes and cells, and other metaphors of machine components that can be used in the design of simple organisms. As has been increasingly argued over the past few years, this approach has had limited success, and can be a barrier to further discoveries within the field [22, 30, 32, 41].

There is disagreement amongst scholars as to whether synbio represents anything qualitatively new. Preston [37] argues that it is only the latest in a line of development that has lasted as long as humans have practiced agriculture, and that biotechnology crossed the ontological line of seeking to control and manipulate plants and animals in the Neolithic. This is a variant of the argument that synbio is simply at one range of a spectrum stretching from 'natural' to 'designed' organisms [28, 40]. Others argue that despite this continuity, the purposeful design and rearranging of biological parts crosses a threshold into novel territory, from 'manipulation' to 'creation' [34]. Whether or not one agrees that the goal of constructing organisms from scratch is qualitatively different from manipulating existing ones (and whether or not one buys into synbio's claims that this will ultimately be achieved), the explicit aim of constructing 'living machines' clearly constitutes an exacerbation of existing attitudes towards living organisms as materials that can, and should, be manipulated at will.

The drive towards standardisation and the widespread use of machine metaphors may be more indicative of 'an underlying awareness of human limitations' than of a questionable desire to conquer nature [28; see also 39]. The very awareness of daunting biological complexity may precipitate the drive for predictable, standardised biological systems for making useful products. However, the repeated statements that the rest of biology needs to adopt the engineering mindset [30] seem to indicate a sense that this is the right approach to studying biology. This reaches beyond methodology into the realms of epistemology and ontology. Way et al. ([30]: p. 151) argued that synbio 'made an impact on the thinking about biological systems, redefining organisms such as microbes previously appreciated for their basic biology or pathogenic properties, in terms of their value for biological redesign'. This drive towards spreading the ontology of organisms-as-machines is worrisome.

The machine metaphor is highly helpful in synbio for analysing parts and their function within the whole, and in some cases for understanding how to create novel, useful organisms based on known principles. However, it also leads to systematic under-appreciation of qualities of organisms that do not fit the language of this master metaphor, such as evolutionary development and ecosystem interactions. This may result in underestimating the side effects of synthetically created organisms in an environment [34], over-confidence in technological fixes, and missed opportunities for scientific understanding [10, 22]. Therefore, the persistent use of these metaphors can be considered an ethical issue that needs to be dealt with responsibly [14].

So, while we can productively use the metaphor of life as machinery, we need to maintain a critical awareness of what this means. As Lakoff and Johnson [1] argued, one of the ways this can be achieved is through counter-narratives and other metaphors. For instance, an alternative to the 'genome as blueprint' sub-metaphor is the 'genome as recipe' metaphor, which takes into account phenomena such as pleiotropy (historically induced redundancy) and epistasis (interactions between genes) [22]. While the recipe metaphor can also be misleading, potentially conveying an idea of a step-bystep manual for making an organism, a plurality of metaphors can serve to counterbalance the predominance of one conception. This may lead to a less skewed perception of how a particular organism might function, not just on its own, but in its environment.

However, the recipe metaphor only speaks to one sub-metaphor of the machine conception, and cannot serve as a grand metaphor of the same order. Embracing the organic system metaphor [8] more fully can be one alternative, and indeed, systemic thinking has long been one of the recommendations from philosophers. Systems biology, another recent computer-based approach to biology that takes a more holistic path of looking at connections within large-scale systems, still represents the engineering mindset, and the two fields have multiple synergies [32]. So far, systems biology has been less adept than synthetic biology in reaching larger publics. More of a real contrast is found in developmental and field biology (e.g. [51]). For public perception, however, important avenues of influence can be found in the realms of art and design. Paul Freemont, synthetic biologist and co-curator of synbio exhibition Grow Your Own... Life After Nature, stated in a video on the Science Gallery Dublin [52]: 'The greatest fear is that society doesn't accept the technology, and that everything around synthetic biology stops'. Using artists in shaping those perceptions is a conscious decision [52]. 


\section{Embracing the Messy: Artists Counter the Standardisation of Synthetic Biology}

Synbio, as argued by artist Oron Catts, 'is one of the first technologies in which there is a very direct move to engineer public acceptance even before the technology is here. I have been to some meetings where it was said that we have to learn from genetic engineering; we have to create public acceptance before we push it. And the solution was to use artists' ([53]: p. 79). However, he continued, 'there is a community of artists who are sophisticated enough and have the experience to try to manipulate this. It might not work, but we need to address such issues and I think these areas need cultural scrutiny' [53]. Aiming at a rather different audience than that of popular science, art is situated to convey the issues of science and the living world from and to the perspective of human beings, but without a necessarily human-centric approach. Like science, art is concerned with creation and control, but often at a different level and for different ends. It also contains centrally elements of playfulness, encouraging imagination and wonder [54-56], which according to Nussbaum ([54]: p. 100) have an 'important role in shaping democratic citizenship'.

There are plenty of examples of artists embracing the project of synbio, both using the same methods and subscribing to the corresponding metaphors. An example of an evocative piece that follows this path is Joe Davis' collaborative work with George Church's lab to record the written information on Wikipedia in DNA. The aim of the project Malus ecclesia (bad church, or apple church) is to create a 'tree of knowledge', inserting the synthetic 'raw DNA' into saplings of the oldest known apple species, malus sieversii (see e.g. [57]). This rich project very much embraces not just the methods, but also the metaphors and mindset, of synbio. However, other artists take the path suggested by Catts in the previous paragraph, including himself, in his projects with partner Ionat Zurr.

\section{Oron Catts and Ionat Zurr}

Catts and Zurr are lead artists at SymbioticA, University of Western Australia, the world's only Centre for Excellence in Biological Arts. They have made a career of more than 20 years of using biological techniques in artworks that question narratives of 'life as a coded program - "biology as information"” ([58]: p. 126). Prolific writers, they state their desire 'to argue for the ethical, cultural, and political importance of experiential engagement with life manipulation, as it can be an effective methodology to confront the complexities and to contest dominant ideologies regarding the life sciences' [58]. They explicitly seek to counter genocentrism and 'genohype' [59] through their work, and complain about their frequent encounters with this phenomenon when their own tissue culture work is described, incorrectly, as genetic artworks [58].

Catts and Zurr have repeatedly made it clear that they consider themselves to have a different 'contract' with society. They seek to 'provoke, question and reveal hypocrisies through different tactics: whether through aesthetic, absurd or subtle confrontations. Allowing loss of control or "engineering futility"; making our audience uneasy is an outcome of our own discomfort' ([60]: pp. 6). This is shown in their art through an embrace of aesthetics of futility and failure. A famous example is the version of Victimless Leather displayed at New York's MoMA in 2008. For this piece they grew immortalised cells over a miniature jacket-shaped biopolymer, as an ironic reflection on future hopes of labgrown leather created without killing animals. In previous exhibitions they had used used a combination of mouse (connective tissue) and human (bone and skin) cells, but this time they used mouse embryonic stem cells, which grew so fast that they clogged up the automated feeding system - the jacket's 'life support' ([61], and email communication from Oron Catts, 7 March 2019). In a publicised act, the curator unplugged ('killed') the cell system before the end of the show, and the artists often refer back to its monstrous shape. Figure 1 shows two other failed instances of the artwork: fungal contamination of the kimono-shaped jacket grown at the Mori Art Museum in Tokyo in 2010 and a mysterious jacket 'melt-down' at the Casino Luxembourg. These situations are prominently featured in the artists' communication of their piece [62, 63], particularly in their references to biological entities' penchant to evade the attempted control of life in the lab.

In a recent exhibition called Biomess (2018), the duo brought together live creatures and specimens from the Western Australia Museum, that 'defy human conventions about identity, gender, procreation' (Zurr, quoted in [64]). The specimens were elegantly displayed as 'luxury goods', in tall, glossy display cases resembling those one might find in a high-end retail store. The result was an exhibition that went against the conventions of both art and science exhibits, but more profoundly, 
challenged conventional ideas about life, organisms, reproduction and death. From sea sponges that can reassemble the original organism after having been disintegrated through a sieve and mixed with other sponge cells, to bearded dragons with the chromosomes of one sex but the physical properties of the other, the exhibition facilitated the realisation that 'we humans are basically quite boring in our understanding of life and what our bodies can do' (Zurr, quoted in [64]). However, humanity's penchant for affecting change was also prominently featured. A tragicomic example is that of the male jewel beetles, which during the 1980s became attracted to a certain type of brown beer bottle, to the extent that they ignored the female beetles, resulting in a reproductive crisis. Finally, a deconstructed incubator held hybridoma cells, merged from primary and immortalised mice cells. As an example of lab-grown organisms that would not have existed without human manipulation, the hybridomas represent the effect of science on the world, the creation of new ecologies that would not have arisen in a 'natural' environment.
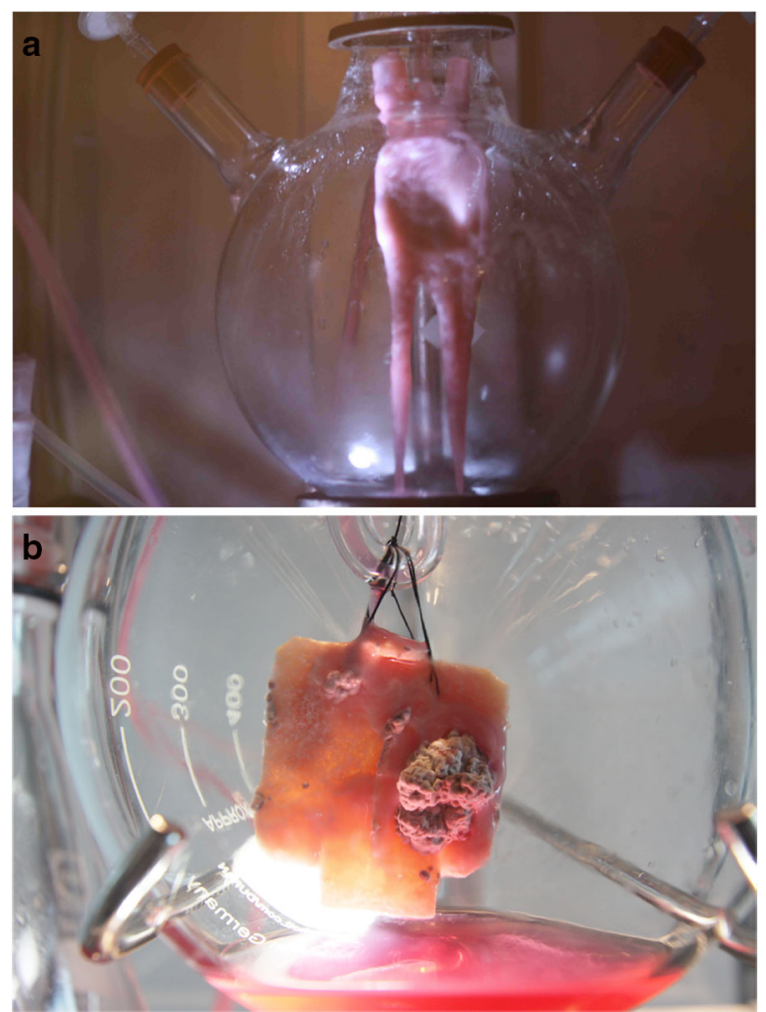

Fig. 1 Oron Catts and Ionat Zurr, Victimless Leather, 2004-pt. a 'Melted' biopolymer mould of jacket, exhibited at Casino Luxembourg. b Protruding fungal growth on jacket at Mori Art Museum, Tokyo. Photos courtesy of the artists
Tarsh Bates: HumanThrush Entanglements

Tarsh Bates has been working for years with Candida albicans, or thrush, a common yeast culture that is symbiotic with human bodies (guts and reproductive organs) and an opportunistic pathogen. She views Candida as a 'companion species' - building on Donna Haraway's work with dogs, but taking the idea of significant others further from our comfortable scales. Bates has pointed to the warfare metaphors used in the discussion of pathogenic Candida ([65]: p. 26), including terms such as 'immunological shields' ([66]: p. 408) and the notion that 'Candida evades the host defense armory' ([67]: p. 1304).

Her focus, however, is on how these and other microorganisms are parts of our self-integral components of our bodies - and she seeks to embrace this through engaging with the yeast outside of the body. In The Unsettling Eros of Contact Zones (2015), she baked bread with Candida, and wished to serve it to the art gallery audience. However, her university employer at first refused her suggestion to serve the bread due to biosafety concerns, although all microorganisms used to leaven the bread were killed in the baking process. Only after a meeting to clarify her intentions, a series of food safety experiments demonstrating that all the microbes were inactive and a 50-page risk management plan that included a public anxiety management section did they consent to have it served (personal communication with Bates, 27 February 2019).

In Control of Cell Morphology in vivo (2014), Candida was explicitly brought up to our scale through

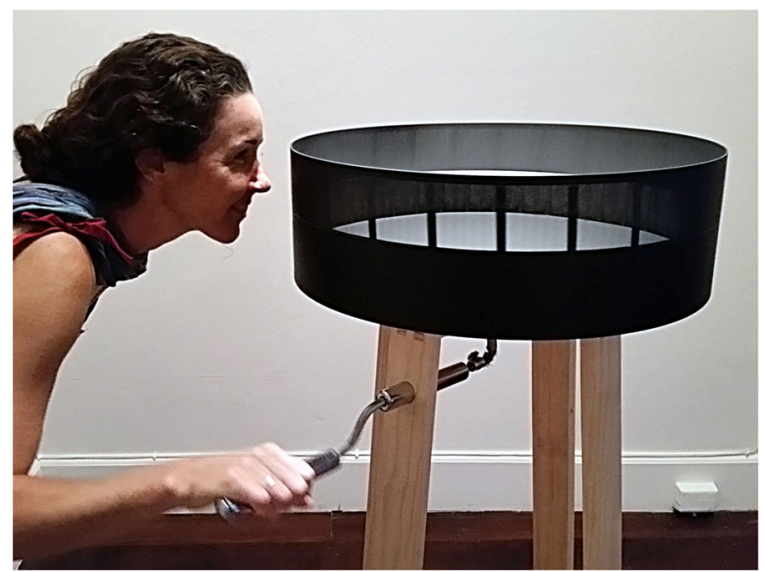

Fig. 2 Tarsh Bates, Control of Cell Morphology in vivo (2014). Image credit: Tarsh Bates, 2016. Courtesy of the artist 
Fig. 3 Ai Hasegawa, I Wanna Deliver a Dolphin (2013). a Still from video. b Explanatory chart of the engineered dolph-human placenta. Courtesy of the artist
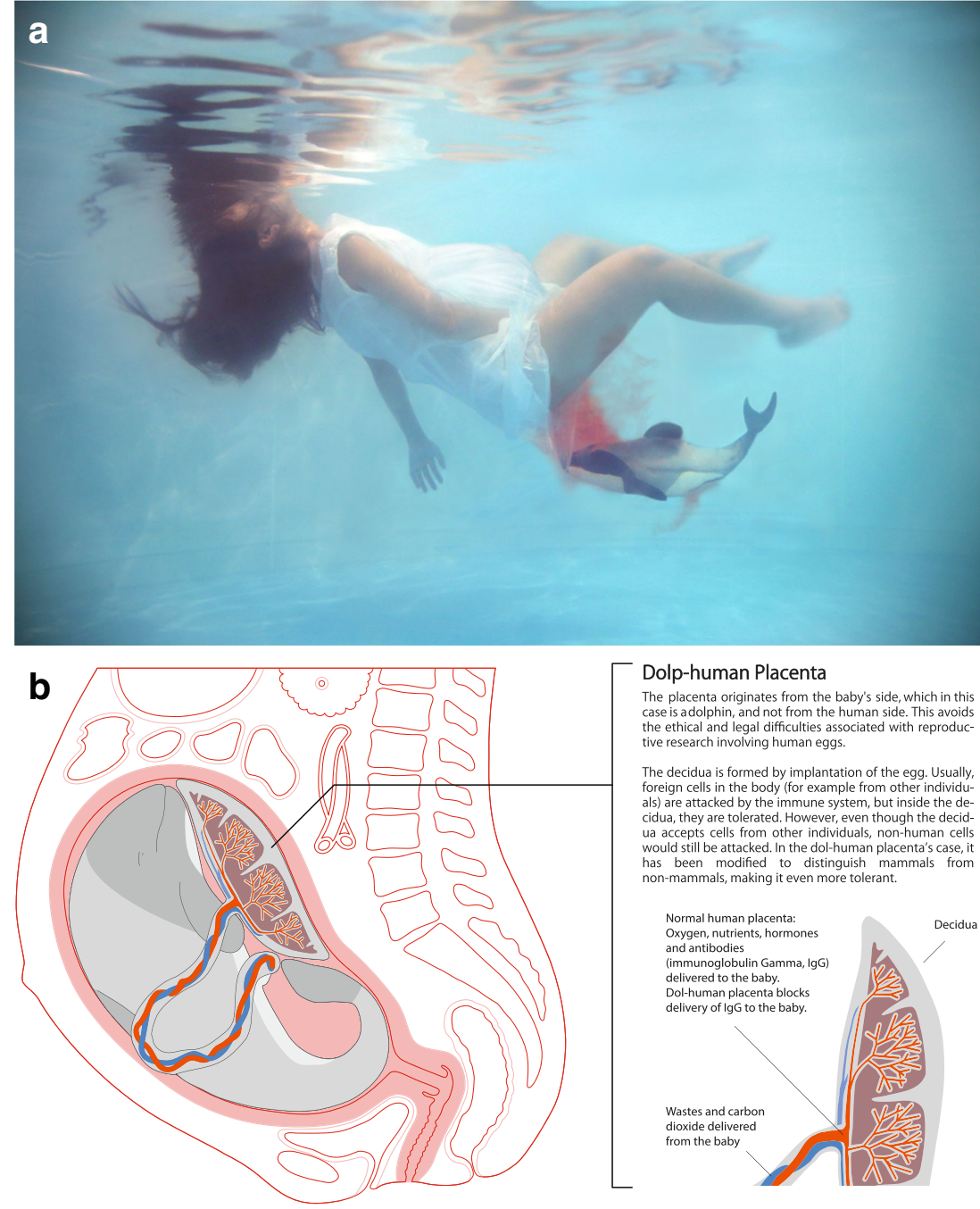

Māui's dolphin (Critically Endangered)

The world's rarest and smallest known subspecies of dolphin. As of 2016, it is estimated that 63 adults ( $95 \%$ confidence there are between 57 and 75 ) Maui's dolphins exist in the world. The main reason for the unnatural Măui deaths are caused by entanglement and drowning in gillnet or trawl fishing. Adults measure between $1.2-1.4 \mathrm{~m}$ and weigh up to $50 \mathrm{~kg}$. The newborn baby is almost the same size as a human baby $(50-60 \mathrm{~cm})$. Lifespan 20 years. New Zealand, West coast of North Island.

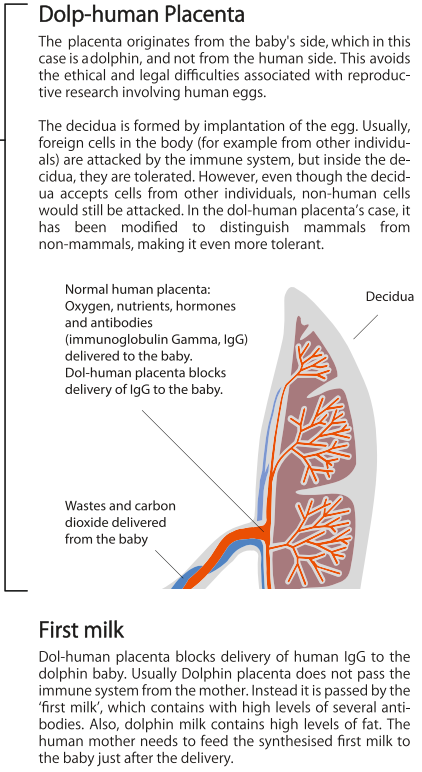

images that could be viewed in a zoetrope, a pre-film animation devise (Fig. 2). The audience, cranking the handle of the devise, would set the images in motion, thus interacting with the Candida in an almost intimate sense, viewing them close-up, but at a safe distance. Pandilovski [68] and Thacker [69] have argued for the importance of embodied temporality in the relationality established by bioart in the presence of the living other, and Bates' work exemplifies this: in engaging with the close-ups of the Candida, we are in control of the terms of our interactions with the organisms, both being able to slow down or speed up the images according to our liking, and to feel at once close and safely remote from the Candida. Bates thus explicitly creates a context of control for something that is not, ordinarily, controllable - and this very context brings our ordinary lack of control into sharp relief. Through facilitating audience encounters with Candida in various forms, and through poetic writing about her entanglements with these microbes that oscillate between companions and parasites, friends and foes, she challenges established ways of thinking of and existing with this yeast that is integral to most of our bodies. 
Fig. 4 Ai Hasegawa, I Wanna Deliver a Dolphin (2013). a Dilemma chart. b Sculpture of dolph-human family. Courtesy of the artist

\section{Dilemma chart (Why don't I get pregnant with...)}
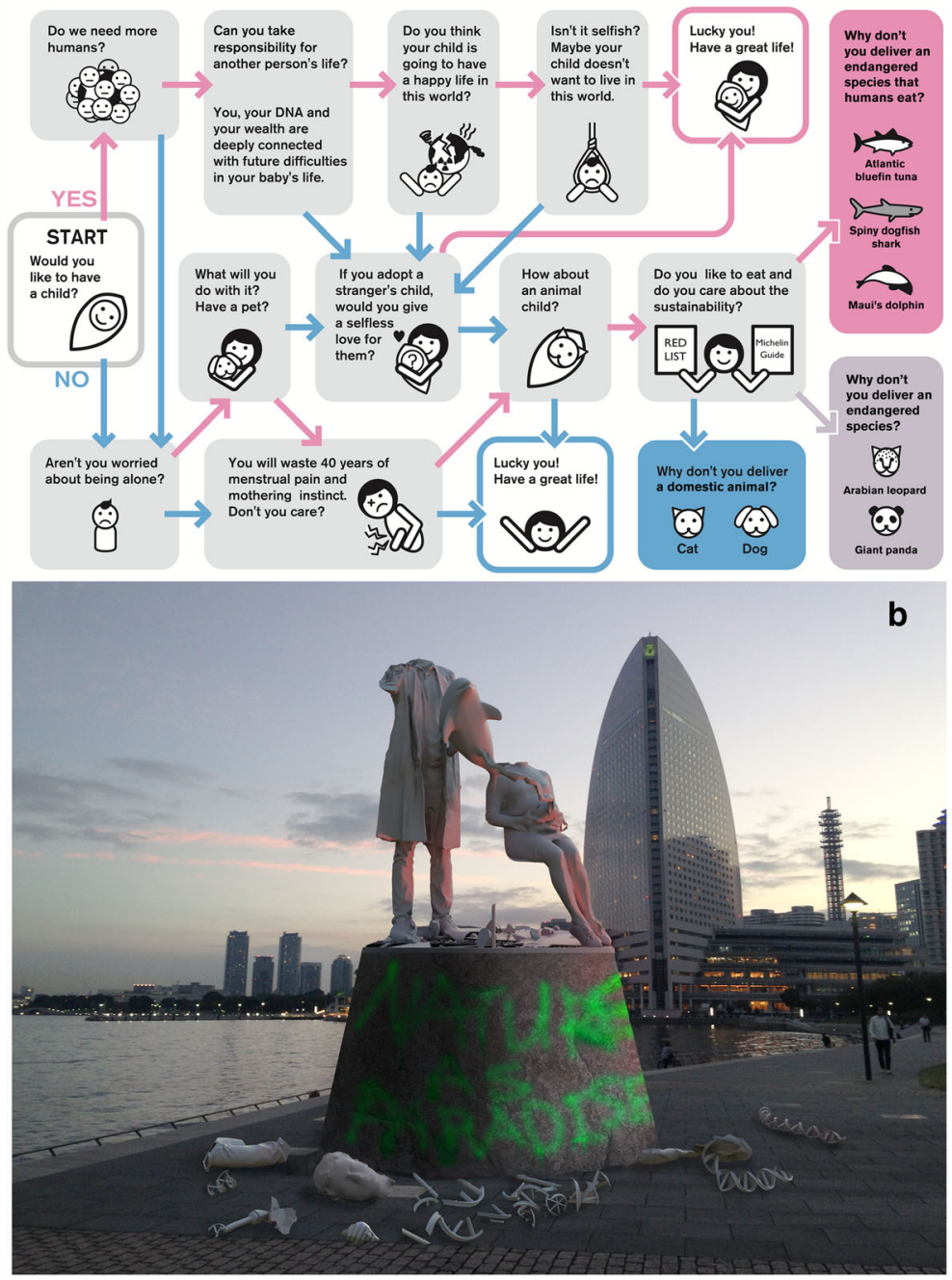

Ai Hasegawa: I Wanna Deliver a Dolphin

In addition to those working with living organisms and laboratory methods, a larger group of artists and designers are relating to developments in the life sciences at the notional level. Ai Hasegawa's I Wanna Deliver a Dolphin (2013) exists in the realm of speculative design, with a proposal of one future application of synthetic biology. The idea for this piece, first developed in $I$ Wanna Deliver a Shark (2012), is that we might deal with human overpopulation and save endangered species through human mothers carrying those species forth in their womb. This would be done through a synthetised cross-species placenta, genetically engineered to not allow antibodies to pass from 'mother' to 'child'. For the second piece in the series, Hasegawa chose the Maui dolphin, which is critically endangered (in 2012, there were an estimated 55 left in the world), with a foetal size close to that of a human foetus.

While the Maui dolphin is no longer commercially fished for due to its endangered status, it often ends its life in fishing nets. Hasegawa deliberately chose dolphins and sharks as types of animals that are popular foods in many Asian countries and brought near extinction by human eating habits (personal communication with Hasegawa, 27 February 2019). A challenging part of the vision was whether you would eat something you had given birth to; if so, it could be an embodied and engaged way for humans to grow their own food. Releasing them into nature would also potentially increase the future food 
supply. Central to the piece was a video of a woman 'giving birth' to a dolphin in a swimming pool (Fig. 3) and bottle-feeding the new-born calf. A cross-section model of the human belly with dolphin foetus was displayed in a smooth plaster finish that seemed to emphasise the hypothetical nature of the scenario. A 'dilemma chart' ('Why don't I get pregnant with...?') sought to help potential parents decide whether to go through with such a process (Fig. 4a). Further complicating this rich piece was a story from a future where dolphins were declared 'non-human persons' in 2013. In this future, all aquariums were shut down as cruel and converted to dolph-human houses, where dolphin babies were born from human mothers. A vandalised sculpture of a dolph-human 'family' was, according to the artist's text, destroyed by 'Nature as Paradise' activists who sought to reintroduce notions of species integrity lost in the cross-species breeding practice (Fig. 4b) [70].

The piece suggests a complex web of possibilities as to our future interactions with animals, giving rise to speculative questions such as the following: Would carrying another animal species within your womb give rise to similar maternal feelings as carrying a human foetus? And would this prevent you from later wanting to eat that particular animal, or other members of its species? What sort of extra responsibility would this kind of procreation entail? Is a similar responsibility required when genetically manipulating life forms in other, less personal and embodied ways [71]?

Through making us think about our relationship to our own bodies and those of other living beings, the above pieces, through quite different means, address life in its complexity, relationality and potentiality. None of them use synbio materially, but both Catts and Zurr and Bates use other forms of biotechnology at the cellular level; they engage with creatures at the micro-level, in ways that bring them up to the scale we can experience with the naked eye. Hasegawa, on the other hand, works in the nominal realm, asking us to imagine what synbio might lead to if some of its visions come to fruition. We are living in a culture in which science and technology have a transformative impact on society that few other fields can match. However, rich artworks such as these provide an invaluable counterpoint to a dominant mechanistic discourse, encouraging a more embodied and holistic approach to biotechnology as embedded in a natural and cultural context $[72,73]$. Perhaps this approach, through showcasing the limits of our ability to control living beings, can engender further understanding of other life forms.

\section{Conclusion}

Synbio presents more continuity than break with previous mechanistic approaches to life. Its engineering approach to understanding and creating life forms can be seen as symptomatic of tendencies within Western societies to standardise and abstract in order to understand. In itself this has, as I have emphasised, been quite helpful in furthering scientific understanding within biology. However, an ontological and ethical danger arises from the conflation of organisms with machines. Although synbio does not necessarily represent a novel ontological approach, the predominance of the machine conception of the organism and the apparent drive to spread the ontological assumptions this entails are causes for concern. The ideas of complete control, reduction and standardisation are part of what imbues synbio with its power [14]. Although this way of perceiving life can lead to important biotechnological innovations, the dominance of the machine conception can provide a hindrance both to further scientific understanding and to relational ways of thinking about living organisms.

I have argued that artworks such as those by Catts and Zurr, Bates and Hasegawa have the capacity to shift our perceptions of the living things around us, through embracing and appreciating the messiness and complexity of even minute forms of life, bringing them up to our level of perception and embedding them in cultural imaginations of our present and future. They can thus serve as counterpoints in a technoscientific discussion that is largely focused on utility, application and risk. Rather than explaining complex organisms by reference to their parts, these works show us a way of thinking about organisms in their environment that, although perhaps not feasible as a scientific approach, at the societal level can serve to balance out the ontology of controllable life.

Acknowledgements A very different version of this article started out as a conference paper at the Politics of the Machines: Art and After conference in Copenhagen in May 2018. I thank Laura Beloff and Morten Søndergaard for inviting me to host the track 'Wet Machines', and the audience for fruitful comments. I am particularly indebted to artist Beloff, biologist Ljiljana Fruk and fellow philosopher Maria Antonia González Valerio for inspiring exchanges during the end panel 'Life in Art-Where does the machine fit in?' I am also grateful to have been able to write parts of this paper during a generous research stay at the Department of Philosophy and Religious Studies at the Norwegian University of Science and Technology, and for the feedback on the paper at a departmental seminar. 
Open Access This article is distributed under the terms of the Creative Commons Attribution 4.0 International License (http:// creativecommons.org/licenses/by/4.0/), which permits unrestricted use, distribution, and reproduction in any medium, provided you give appropriate credit to the original author(s) and the source, provide a link to the Creative Commons license, and indicate if changes were made.

\section{References}

1. Lakoff G, Johnson M (1980) Metaphors we live by. University of Chicago Press, Chicago

2. Allen GE (2005) Mechanism, vitalism and organicism in late nineteenth and twentieth-century biology: the importance of historical context. Stud Hist Philos Biol Biomed Sci 36(2):261-283. https://doi.org/10.1016/j. shpsc.2005.03.003

3. Nicholson DJ (2012) The concept of mechanism in biology. Stud Hist Philos Biol Biomed Sci 43(1):152-163. https://doi.org/10.1016/j.shpsc.2011.05.014

4. Ruse M (2005) Darwinism and mechanism: metaphor in science. Stud Hist Philos Biol Biomed Sci 36(2):285-302. https://doi.org/10.1016/j.shpsc.2005.03.004

5. Bechtel W (2015) Can mechanistic explanation be reconciled with scale-free constitution and dynamics? Studies in history and philosophy of science. Stud Hist Philos Biol Biomed Sci 53:84-93. https://doi.org/10.1016/j. shpsc.2015.03.006

6. Church G, Regis E (2012) Regenesis: how synthetic biology will reinvent nature and ourselves. Basic Books, New York

7. Elfick A, Endy D (2014) Synthetic biology: what it is and why it matters. In: Ginsberg AD, Calvert J, Schyfter P, Elfick A, Endy D (eds) Synthetic aesthetics. investigating synthetic biology's designs on nature. The MIT Press, Cambridge, MA, pp 3-25

8. Konopka AK (2002) Grand metaphors of biology in the genome era. Computers \& Chemistry 26(5):397-401. https://doi.org/10.1016/S0097-8485(02)00024-4

9. Nicholson DJ (2014) The machine conception of the organism in development and evolution: a critical analysis. Stud Hist Philos Biol Biomed Sci 48(Part B):162-174. https://doi. org/10.1016/j.shpsc.2014.08.003

10. Avise JC (2001) Evolving genomic metaphors: a new look at the language of DNA. Science 294(5540):86-87. https://doi. org/10.1126/science. 294.5540 .86

11. Brown TL (2003) Making truth: metaphor in science. University of Illinois Press, Urbana

12. Keller EF (1995) Refiguring life: metaphors of twentiethcentury biology. Columbia University Press, New York

13. Otis L (2001) Networking: communicating with bodies and machines in the nineteenth century. The University of Michigan Press, Ann Arbor

14. McLeod C, Nerlich B (2017) Synthetic biology, metaphors and responsibility. Life Sciences, Society and Policy 13:113. https://doi.org/10.1186/s40504-017-0061-y

15. Price DJDS (1964) Automata and the origins of mechanism and mechanistic philosophy. Technol Cult 5(1):9-23. https://doi.org/10.2307/3101119
16. Descartes R (2006 [1637]) A discourse on the method (I. Maclean, Trans.). Oxford University Press, Oxford

17. Fløistad G (1991) Filosofi og vitenskap: Fra renessansen til vår egen tid. Universitetsforlaget, Oslo

18. Hume D (1998 [1779]) Dialogues concerning natural religion (2nd ed). Hackett, Indianapolis

19. Boudry M, Pigliucci M (2013) The mismeasure of machine: synthetic biology and the trouble with engineering metaphors. Stud Hist Philos Biol Biomed Sci (PartB) 44(4): 660-668. https://doi.org/10.1016/j.shpsc.2013.05.013

20. Suzuki DT, Knudtson P (1990) Genethics: the ethics of engineering life (Rev. edn.). Harvard University Press, Cambridge, MA

21. Hein H (1972) The endurance of the mechanism: vitalism controversy. Journal of the History of Biology 5(1):159-188

22. Pigliucci M, Boudry M (2011) Why machine-information metaphors are bad for science and science education. Science \& Education 20(5-6):471

23. Leduc S (1912) La Biologie Synthétique. A Poinat, Paris

24. Keller EF (2009) What does synthetic biology have to do with biology? BioSocieties 4(2-3):291-302. https://doi. org/10.1017/S1745855209990123

25. Gilbert SF, Sarkar S (2000) Embracing complexity: organicism for the 21st century. Developmental Dynamics 219(1):1-9

26. Calvert J (2013) Engineering biology and society: reflections on synthetic biology. Science, Technology and Society 18(3):405-420. https://doi.org/10.1177/0971721813498501

27. European Commission. Directorate General for Research (2005) Synthetic biology: applying engineering to biology: report of a NEST high-level expert group. Office for Official Publications of the European Communities, Brussels. EUR 21796

28. Lewens T (2013) From bricolage to BioBricks ${ }^{\mathrm{TM}}$ : synthetic biology and rational design. Stud Hist Philos Biol Biomed Sci (Part B) 44(4):641-648. https://doi.org/10.1016/j. shpsc.2013.05.011

29. Black JB, Perez-Pinera P, Gersbach CA (2017) Mammalian synthetic biology: engineering biological systems. Annual Review of Biomedical Engineering 19(1):249-277. https://doi.org/10.1146/annurev-bioeng-071516-044649

30. Way JC, Collins JJ, Keasling JD, Silver PA (2014) Integrating biological redesign: where synthetic biology came from and where it needs to go. Cell 157(1):151-161. https://doi.org/10.1016/j.cell.2014.02.039

31. Endy D (2005) Foundations for engineering biology. Nature 438(7067):449-453

32. Smolke CD, Silver PA (2011) Informing biological design by integration of systems and synthetic biology. Cell 144(6): 855-859. https://doi.org/10.1016/j.cell.2011.02.020

33. Ancillotti M, Rerimassie V, Seitz SB, Steurer W (2016) An update of public perceptions of synthetic biology: still undecided? NanoEthics 10(3):309-325. https://doi.org/10.1007 /s11569-016-0256-3

34. Boldt J (2018) Machine metaphors and ethics in synthetic biology. Life Sciences, Society and. Policy 14(1):12. https://doi.org/10.1186/s40504-018-0077-y

35. iGEM (2018). International genetically engineered machine competition. http://igem.org/About. Accessed 28 Feb 2019

36. Lee ME, DeLoache WC, Cervantes B, Dueber JE (2015) A highly characterized yeast toolkit for modular, multipart 
assembly. ACS Synthetic Biology 4(9):975-986. https://doi. org/10.1021/sb500366v

37. Preston B (2013) Synthetic biology as red herring. Stud Hist Philos Biol Biomed Sci (Part B) 44(4):649-659. https://doi. org/10.1016/j.shpsc.2013.05.012

38. Schyfter P (2013) How a 'drive to make' shapes synthetic biology. Stud Hist Philos Biol Biomed Sci (Pat B) 44(4): 632-640. https://doi.org/10.1016/j.shpsc.2013.05.010

39. O'Malley MA (2009) Making knowledge in synthetic biology: design meets kludge. Biological Theory 4(4):378-389. https://doi.org/10.1162/BIOT_a_00006

40. Galdzicki M, Rodriguez $\bar{C}$, Chandran D, Sauro HM, Gennari JH (2011) Standard biological parts knowledgebase. PLoS ONE 6(2):e17005. https://doi. org/10.1371/journal.pone.0017005

41. Porcar M (2016) Synthetic biology: from having fun to jumping the gun. Nanoethics 10(1):105-109. https://doi. org/10.1007/s11569-016-0251-8

42. Vaage NS (2017) Fringe biotechnology. BioSocieties 12(1): 109-131. https://doi.org/10.1057/s41292-016-0033-0

43. Braun E, Marom S (2015) Universality, complexity and the praxis of biology: Two case studies. Stud Hist Philos Biol Biomed Sci 53: 68-72. https://doi.org/10.1016/j.shpsc.2015.03.007

44. Smith JM (2000) The concept of information in biology. Philosophy of Science 67(2):177-194

45. Pauwels E (2013) Mind the metaphor. Nature 500:523-524. https://doi.org/10.1038/500523a

46. Gibson DG, Venter JC et al (2010) Creation of a bacterial cell controlled by a chemically synthesized genome. Science 329(5987):52-56. https://doi.org/10.1126/science.1190719

47. BBC News (2010) How scientists made 'artificial life'. 20 May. https://news.bbc.co.uk/2/hi/science/nature/8695992. stm. Accessed 02 Sept 2015

48. Presidential Commission for the Study of Bioethical Issues (2010) New directions: the ethics of synthetic biology and emerging technologies. Washington, D.C. http://bioethics. gov/sites/default/files/PCSBI-Synthetic-Biology-Report12.16.10 0.pdf

49. Blümel $\bar{C}$ (2016) Enrolling the toggle switch: visionary claims and the capability of modeling objects in the disciplinary formation of synthetic biology. NanoEthics 10(3): 269-287. https://doi.org/10.1007/s11569-016-0276-z

50. Mitchell WJT (2002) The work of art in the age of biocybernetic reproduction. Artlink 22(1):10-17

51. Margulis L, Sagan D (2000) What is life? University of California Press, Berkeley, CA

52. Science Gallery Dublin (2013). Grow your own... at Science Gallery. https://www.youtube.com/watch?v=RaN3 Soqx104. Accessed 01 Oct 2019

53. Catts O (2011) Art practice in the form of "tissue culture". In: Deifel V, Kraeftner B, Widrich V (eds) An envelope for arts, sciences, politics and us. Mixing realities and mediating myths \& methods. Springer, Wien, pp 75-79

54. Nussbaum MC (2010) Not for profit: why democracy needs the humanities. Princeton University Press, Princeton, NJ

55. Bennett J (2001) The enchantment of modern life: attachments, crossings, and ethics. Princeton University Press, Princeton, NJ

56. Holmberg T, Ideland M (2016) Imagination laboratory: making sense of bio-objects in contemporary genetic art. The Sociological Review 64(3):447-467
57. Yetisen AK, Davis J, Coskun AF, Church GM, Yun SH (2015) Bioart. Trends in Biotechnology 33(12):724-734. https://doi.org/10.1016/j.tibtech.2015.09.011

58. Catts O, Zurr I (2008) The ethics of experiential engagement with the manipulation of life. In: Da Costa B, Philip K (eds) Tactical biopolitics. Art, activism, and technoscience. The MIT Press, Cambridge, MA, pp 125-142

59. Holtzman NA (1999) Are genetic tests adequately regulated? Science 286(5439):409. https://doi.org/10.1126 /science.286.5439.409

60. Catts O (2012) Why artists play with life. In: Afman S, James E (eds) Waag Society bioart special. Waag Society, Amsterdam, pp 5-6

61. Schwartz J (2008) Museum kills live exhibit. The New York Times, May 13. http://www.nytimes.com/2008/05/13 /science/13coat.html?_r=0. Accessed 28 Feb 2019

62. Catts O, Zurr I (2014) Countering the engineering mindset: the conflict of art and synthetic biology. In: Ginsberg AD, Calvert J, Schyfter P, Elfick A, Endy D (eds) Synthetic aesthetics. -. The MIT Press, Cambridge, MA, pp 27-37

63. Radomska M (2016) Uncontainable life: a biophilosophy of bioart. Linköping University, Linköping

64. Wynne E (2018) Biomess exhibition challenges conventional ideas of what belongs in a gallery. ABC News, 16 September

65. Bates T (2015) We have never been Homo sapiens: Candida homo naturecultures. Platform: Journal of Media and Communication 6(2):16-32. https://platformjmc.files. wordpress.com/2015/10/bates_platformvol6-2_2015.pdf . Accessed 12 Novemner 2019

66. Gow NAR, Hube B (2012) Importance of the Candida albicans cell wall during commensalism and infection. Current Opinion in Microbiology 15(4):406-412

67. Cheng S-C, Joosten LAB, Kullberg B-J, Netea MG (2012) Interplay between Candida albicans and the mammalian innate host defense. Infection and Immunity 80(4):1304 1313. https://doi.org/10.1128/IAI.06146-11

68. Pandilovski M (2017) The phenomenology of (non)habitual spaces for the bioarts. In: Hiebert T (ed) Naturally postnatural. Noxious Sector Press, Victoria, pp 139-164

69. Thacker E (2005) The global genome: biotechnology, politics, and culture. The MIT Press, Cambridge, MA

70. Hasegawa A (2013) I wanna deliver a dolphin.... In: Ginsberg AD et al (eds) Grow your own... life after nature. Science Gallery, Dublin

71. Vaage NS (2016) Grow your own views on knowledge: visions and framings of synthetic biology. In: Vaage NS, Slaattelid RT, Haagensen TK, Smith SL (eds) Images of knowledge: the epistemic lives of pictures and visualisations. Peter Lang, Frankfurt am Main, pp 127-159

72. González Valerio MA (2012) BioArt on the verge of aesthetic ontology. Annales, Ser hist sociol 22:327-334

73. Hauser J (2008) Observations on an art of growing interest: toward a phenomenological approach to art involving biotechnology. In: da Costa B, Philip K (eds) Tactical biopolitics. Art, activism, and technoscience. The MIT Press (Leonardo Books), Cambridge, MA, pp 83-104

Publisher's Note Springer Nature remains neutral with regard to jurisdictional claims in published maps and institutional affiliations. 